\section{HIGH DOSAGE OF ARIPIPRAZOLE INDUCED PRIAPISM: A CASE REPORT}

\section{To the Editor:}

Priapism is a persistent erection, usually painful, that is not necessarily associated with stimulation or sexual desire. Priapism might caused by medical treatment provided from a clinical practice. There are some case reports about antipsychoticrelated priapism. ${ }^{1,2}$ However, there are few reports about aripiprazole-induced priapism. We present a case of a patient who developed priapism during treatment with aripiprazole.

Mr. B, a 24 year-old male, is a case of psychotic disorder. He had idle daily life for four years. Four months ago, he started having auditory hallucination, delusion of being monitored, delusion of persecutory, bizarre delusion, and magical thinking. He was admitted to our acute psychiatry ward due to psychotic deterioration. We initially prescribed aripiprazole $10 \mathrm{mg} /$ day. Nine days later we increased the dosage to $20 \mathrm{mg} /$ day. After 8 days of this dosage, he complained of strange feelings after his evening does of aripiprazole (ie, he thought that somebody teased him). We increased the aripiprazole dosage to $25 \mathrm{mg} /$ day for the irrational thought. But, he felt the condition worsen. After clarification, penile erection was noted. He stated that this would persist all day. Priapism was then diagnosed. He was bothered almost all day, especially when he lay down. We switched his antipsychotic to olanzapine $10 \mathrm{mg} / \mathrm{day}$. The priapism soon disappeared.
In this case, we found priapism was related to the dosage of aripiprazole.

Priapism could occur in any age, but is especially common from $20-50$ years of age. ${ }^{3}$ Sood and colleagues ${ }^{1}$ identified 50 case reports of priapism linked to aripiprazole, clozapine, olanzapine, quetiapine, risperidone, and ziprasidone. The mechanism of priapism associated with antipsychotics is not clear, however, it is thought to be related to $\alpha$-adrenergic blockage mediated by the $\alpha_{1}$ receptors in the corpora cavernosa of the penis. ${ }^{1,3}$ Aripiprazole exhibits high affinity for $D_{2}$ and $D_{3}$ and $5-H_{1 A}$ and $5-\mathrm{HT}_{2 \mathrm{~A}}$ receptors, and moderate affinity for $\mathrm{D}_{4}, 5-\mathrm{HT}_{2 \mathrm{C}}$, and $5-\mathrm{HT}_{7}, \alpha_{1}$-adrenergic and $\mathrm{H}_{1}$ receptors. ${ }^{4}$ In this case, priapism was not presetn as an adverse effect when the dosage of aripiprazole was $<20 \mathrm{mg} /$ day. Priapism only presented in high dosage of aripiprazole treatment ( $\geq 20 \mathrm{mg} /$ day). Dosage related priapism was suspected. There is low risk of priapism in patients treated with any dosage of aripiprazole. However, when the dosage of aripiprazole is increased, priapism should be reminded.

Sincerely,

Wen-Yu Hsu, MD

Nan-Ying Chiu, MD

Chieh-Hui Wang, MD

Cheng-Yeh Lin, MD

\section{REFERENCES}

1. Sood S, James W, Bailon MJ. Priapism associated with atypical antipsychotic medications: a review. Int Clin Psychopharmacol. 2008:23(1):9-17.

2. Wang CS, Kao WT, Chen CD, et al. Priapism associated with typical and atypical antipsychotic medications. Int Clin Psychopharmacol. 2006;21(4):245-248.
3. Andersohn F, Schmedt N, Weinmann S, et al. Priapism associated with antipsychotics: role of alpha1 adrenoceptor affinity. J Clin Psychopharmacol. 2010;30(1):68-71.

4. Uzun S, Kozumplik O, Mimica N, Folnegovic-Smalc V. Aripiprazole: an overview of a novel antipsychotic. Psychiatr Danub. 2005;17(1-2):67-75.

Dr. Hsu attending in the Department of Psychiatry, Lu-Tung Branch of Changhua Christian Hospital; and trainee, Division of Mental Health and Addiction Medicine, Institute of Population Health Sciences of National Health Research Institutes. Dr. Chiu is Director, Department of Psychiatry of $\mathrm{CCH}$ League of Affiliated Hospitals; Superintendent, Lu-Tung Branch of Changhua Christian Hospital; Assistant Professor, Chung Shan Medical University; Assistant Professor, National Changhua University of Education; Assistant Professor, Chang Jung Christian University Assistant Professor, National Hsinchu University of Education; Superintendent, Taiwanese Society of Psychiatry; Director, Taiwan Association Agains Depression; Director, Taiwan Society of Addiction Science; Director, Taiwan Society of Suicidology; and Director, Taiwan Society of Biological and Neuropsychopharmacology. Dr. Wang is head of the Department of Psychiatry, Lu-Tung Branch of the Department of Psychiatry, Lu-Tung Branch of Changhua Christian Hospital, and Lecturer at Chang Jung Christian University. Dr. Lin is resident in the Department of Psychiatry at Changhua Christian Hospital.

Faculty Disclosures: Dr. Hsu has received honoraria from Janssen-Cilag and Otuka; and has received funding from AstraZeneca, GlaxoSmithKline, and Sanofi-aventis; and he has participated in research collaboration with Janssen-Cilag, Lundbeck, MSD and Otuka. Dr. Chiu has received honoraria from Eli Lilly, Janssen-Cilag, Otuka, Pfizer, and sanofi-aventis; has received funding from Otuka to attend scientific meetings; has participated in research collaboration with Janssen-Cilag, Lundbeck, MSD and Otuka. Dr. Wang has received honoraria from Eli Lilly, JanssenWalag, Pfizer, sanofi-aventis; has received funding from Otuka; and has participated in research collaboration with Janssen-Cilag, MSD, and Otuka. Dr. Lin reports no affiliations with or financial interests in any organization that may pose a conflict of interest.

Submitted for publication: September 9, 2010, Accepted for publication: September 21, 2010. First published online: August 1, 2011.

Please direct all correspondence to: Nan-Ying Chiu MD, Department of Psychiatry, Lu-Tung Branch of Changhua Christian Hospital, 888 Lu-Tung Road LuKang Town, Changhua County, Taiwan; Tel: 886 LuKang Town, Changhua County, Taiwan; Tel: 886-
4-7789595 ext. 1584, Fax: 886-4-7769780; E-mail: 400850@cch.org.tw. 